\title{
MASS-FLOWERING OF A TROPICAL SHRUB (HYBANTHUS \\ PRUNIFOLIUS): INFLUENCE ON POLLINATOR ATTRACTION AND MOVEMENT
}

\author{
Carol K. Augspurger ${ }^{1}$ \\ Department of Ecology and Evolutionary Biology, University of Michigan, Ann Arbor, Michigan 48109
}

Received March 20, 1979. Revised October 29, 1979

There are conflicting views about the regulation of gene flow in tropical plants (see Corner, 1954; Baker, 1959; Federov, 1966; Ashton, 1969; Bawa, 1974). Characteristics proposed to promote outbreeding include a long flowering period, asynchronous flowering, dioecism, protandry, protogyny, and self-incompatibility. One feature which should yield reduced gene flow is mass-flowering of the individual plant. This study concentrates on this feature and how it influences pollinator movement and consequent gene flow.

Among species, the flowering phenology of the individual plant varies markedly. Among tropical plants, Janzen (1971) distinguished between two extreme patterns of daily flower abundance. In the first pattern, later designated "steady state" (Gentry, 1974), the individual plant produces small numbers of new flowers almost daily over an extended period (usually greater than $2 \mathrm{mo}$, often for 6-12 mo [Gilbert, 1975; Stiles, 1975]). In the second pattern, designated "big bang" (Gentry, 1974) or "mass-flowering" (Heinrich and Raven, 1972), an individual produces large numbers of new flowers each day over a short period (often less than one week).

Earlier observations suggest that these contrasting flowering patterns attract different types of pollinators. Pollinators visiting steady-state individuals are thought to be low in number and in species richness, to shift to new plants after a shorter foraging period, and to move longer distances between conspecific individuals, relative to pollinators visiting mass-flow-

\footnotetext{
${ }^{1}$ Present address: Department of Botany, University of Illinois, Urbana, Illinois 61801.
}

ering individuals (Heinrich and Raven, 1972; Frankie et al., 1974). As a result, steady-state individuals may experience a higher amount of cross-pollination and/or percentage fruit and ovule set than do mass-flowering individuals. The amount also depends on the compatibility system of the species.

Several pollination studies of tropical species with the steady-state pattern are available (Janzen, 1968; Baker, 1973; Linhart, 1973; Kennedy, 1974; Gilbert, 1975; Stiles, 1975). No experimental study of pollination of mass-flowering individuals is available for any tropical species (but see Wolf, 1970; Borrero, 1972; Carpenter, 1976; Frankie et al., 1976). Carpenter (1976) speaks of our lack of understanding of the "anomaly" of mass-flowering in tropical plants.

This study tests two hypotheses: 1) Mass-flowering of the individual plant attracts a large number and high species richness of "opportunistic" (Baker, 1973) pollinators, that is, pollinators with density-dependent foraging behavior (Janzen, 1967; Heinrich and Raven, 1972; Baker, 1973; Beattie et al., 1973; Gentry, 1974; Frankie et al., 1976). 2) Mass-flowering of the individual plant results in low amounts of inter-plant movement because pollinators remain constant for long periods to the large number of flowers on a single plant (Janzen, pers. comm. in Frankie et al., 1974). This constancy can have two consequences depending on breeding system: low fruit set in self-incompatible species and high fruit set and low crosspollination in self-compatible species.

The species studied, Hybanthus prunifolius (Schult.) Schulze (Violaceae), is a 
tropical mass-flowering shrub. Field observations were made in 1975-1976.

\section{FLoRAL Biology}

On the study site, Barro Colorado Island in Panama, the shrub is common. It occurs in patches scattered widely over the island. The mean distance from one reproductive individual to its nearest reproductive neighbor is $2.6 \mathrm{~m}$ ( $\mathrm{SD}=2.9, N=$ 80 at 4 sites). It is difficult to locate spatially isolated individuals. The average height of the reproductive individuals sampled is $2.5 \mathrm{~m}$ (range $=1.1-4.5 \mathrm{~m}, N=$ 80). A shrub bears an average of 226 flowers per flowering period $(S D=199$, range $=1-1,188, N=80$ ).

Phenology and synchrony.-Flowering is restricted to the dry season from midDecember to late April or early May. The specific time of flowering varies depending on the rain pattern during the dry season. Flowering begins 6-7 days after a heavy rain following a period of drought.

Hybanthus is characterized by an extremely high degree of both intra-individual and intra-population flowering synchrony. An individual shrub flowers an average of 3.7 days (SD $=1.1, N=70$ ) with $62 \%$ of its flowers open on one peak day. The local population flowers for an average of 6.5 days (range $=5-8, N=9$ ) and there are some flowers in the forest as a whole for 8-10 days $(N=2)$.

Floral morphology. - The white zygomorphic flowers are borne solitarily in the leaf axils. The greatly enlarged anterior petal, $42 \mathrm{~mm}$ long, has a narrow yellow nectar guide. This petal hangs downward and is used as a landing platform by some visitors. The upper portion of the corolla is $11 \mathrm{~mm}$ long and $8 \mathrm{~mm}$ wide. Analysis by ultra-violet photography (transmission range $=300-400 \mathrm{~nm}$ with peak transmission at $360 \mathrm{~nm}$ ) reveals strong UV reflection by the upper corolla, but weak reflection by the foliage, anterior petal and nectar guide.

Inside the corolla, flower parts are complex. They are similar in basic structure and function to other members of the Vio- laceae (see Beattie, 1971, for details and drawings of Viola spp.). Each of the two anterior stamens bears a long appendage which projects to the deepest part of the corolla. These appendages secrete nectar. The anthers are completely enclosed by overlapping, membranous appendages of the connectives which clasp the style tightly and prevent release of pollen. The style is hollow and flexible at its base. There is no stigmatic surface. Instead there is a small opening into a stigmatic chamber through which a mucilagenous droplet is exuded when the style is deflected upwards or sideways. This complexity requires rather precise movements by a visitor to effect pollination.

Pollination mechanism.-Pollination in Hybanthus results when the head or thorax of an insect visitor causes deflection of the style as the proboscis probes for the deeply located nectar. As a result, the mucilagenous droplet appears at the stigmatic opening and pollen on the visitor's body sticks to it. Deflection also opens the cone of connective appendages causing dry pollen to fall downward onto the dorsal surface of a prone visitor. As the visitor leaves with its new load of pollen, the style springs back into place. The cone of appendages closes. The droplet with pollen grains moves into the stigmatic opening. Visitation is, therefore, a prerequisite for any pollination to occur. Furthermore, the pollen must come from a previously visited flower. The relative positions of the stigmatic opening and connective appendages, plus movements of the visitor preclude the possibility of self-pollination within a given flower. This complex pollination mechanism is similar to that of Viola spp. which Beattie (1971) describes in more detail.

Flower and pollen anthesis; nectar schedule. - Each flower lasts one day. The long anterior petal uncurls at dawn (about $0600 \mathrm{~h}$ ) at which time pollen maturation is complete. The flower exudes a faintly sweet odor. No color changes of the corolla occur through the day. By $1800 \mathrm{~h}$ the anterior petal has curled up.

Nectar production begins before dawn. 
Nectar is abundant by $0630 \mathrm{~h}$, the time when visitation usually begins. Nectar was removed from covered flowers by microcapillaries each hour from 0630 until 1730. Nectar secretion per hour diminishes as the day proceeds. Total nectar secretion equals 7.8 microliters per flower per day $(\mathrm{SD}=2.6, N=11$ ). However, when nectar of covered flowers is removed only once, at $1800 \mathrm{~h}$, total nectar secretion equals 2.4 microliters per flower per day (SD $=1.1, N=13)$. It would appear either that nectar removal stimulates additional nectar production, or that nectar is reabsorbed before $1800 \mathrm{~h}$ if it is not removed.

Breeding system.- The flower is selfcompatible but an outside agent is required to effect pollination. Two sets of experiments were performed to determine these characteristics. First, 229 unopened flowers on three shrubs were covered with cheesecloth to exclude visitors. Flowers were not emasculated. All these flowers fell off by the fifth day following flowering. Dissection of all ovaries revealed only two with any swollen ovules. Both of these ovaries had only one of 29 ovules swollen. Ovaries on uncovered flowers (thousands were examined in experiments described below) having four or fewer swollen ovules invariably aborted soon after the fifth day following flowering. Pollination, therefore, requires an external agent.

The compatibility system was determined on four individuals by artificial transfer of pollen with the use of forceps. Thirty bagged flowers were self-pollinated, 15 using pollen of the same flower, 15 using pollen from other flowers on the same individual. Eighteen of 30 flowers set fruit five days following flowering. Of these 18 , seven eventually developed into mature fruits. The seeds of these fruits successfully germinated and produced healthy seedlings. Further indirect evidence of self-compatibility comes from observations that an isolated individual sets fruit even when no other individuals are in flower. The level of fruit set was similar in cross-pollination studies. Of eight flowers cross-pollinated, using pollen from three neighboring plants, six set fruit at five days and two became mature fruits.

Detection of pollination. - The ovary is 3-4 mm long. If unpollinated, the ovary may swell to 7-8 $\mathrm{mm}$ in the four days following flowering. Usually by the fourth day, and almost always by the fifth day following flowering, an unpollinated ovary aborts or falls from the shrub upon gentle touch. In contrast, the pollinated ovary swells to 9-11 $\mathrm{mm}$ by the fifth day after flowering and remains attached upon touch. Thus, a count of attached versus aborted ovaries on the fifth day after flowering gives an accurate measure of pollination of flowers.

Dissection of pollinated ovaries on day 5 indicates ovules already swollen to their maximum (mature) size. Detection of swollen ovules may be delayed until the fruit is mature because both swollen and unswollen ovules remain intact during maturation of seeds. Thus, a count of swollen versus unswollen ovules gives an estimate of pollination of ovules.

Fruit development; seed dispersal.The pollinated ovary continues to swell into a 3-valved capsule averaging $17 \mathrm{~mm}$ (range $=11-20$ ) at maturity. Fruit and seed development is complete one month following flowering. All pollinated ovaries do not complete fruit development. Abortion of fruits occurs in those with a low number of pollinated ovules and in those with seed predators. Likewise all pollinated ovules in non-aborted fruits do not develop into mature seeds. In determining pollination levels, these events point out the importance of measuring fruit and ovule set very shortly after visitation rather than at the time of mature fruits and seeds.

Each valve of the capsule bears up to ten ovules. The average number of ovules per capsule per individual is 25.7 ( $\mathrm{SD}=$ 2.6, $N=87$ ). The mature capsule per individual has an average of 5.7 seeds ( $\mathrm{SD}=$ $1.6, N=87)$. The mature capsule explodes, mechanically expelling the seeds. 


\section{METHODS}

To test the first hypothesis, it was necessary not only to quantify visitors attracted, but also to identify which visitors were actually effective pollinators. Effectiveness of pollinators was determined by direct observation of visitor behaviors and inferred indirectly from measurements of fruit and ovule set resulting from different sets of visitors. Direct observations were made under two extremes of population synchrony, highly synchronized and highly asynchronized. This design, described below, tested the effect of abundance of flowers on attraction of visitors depending on whether the mass-flowering individual was flowering alone or with the remainder of the population.

I observed flowering for three days in March, 1975 and five days in April, 1976 during the brief, natural flowering period when the population was highly synchronized. In contrast, for 20 days in January, March, and April, 1976, I observed individuals induced experimentally to flower by sprinkling shrubs with water. By design, an individual's peak flowering day in this induced group seldom overlapped with any other individual. The population flowering was highly asynchronized. Additionally, a small population was induced to flower synchronously. Three of the 20 observation days in the experimental area were of individuals in this small population. One individual shrub was observed per day.

Beginning at $0700 \mathrm{~h}$ and ending at 1600 $h$ each day, observations were made in alternating $15 \mathrm{~min}$ intervals, giving a total of $4 \frac{1}{2} \mathrm{~h}$ of observation per day. Very few visitors were observed before $0700 \mathrm{~h}$ and after $1600 \mathrm{~h}$. All visitors and their abundances were noted for each interval. Common visitors were collected for identification, size measurements, and location and analysis of pollen load. C. Michener, University of Kansas, identified the $\mathrm{Hy}$ menoptera, specimens of which are deposited in the Entomological Museum of the University of Kansas.
To test the second hypothesis, movement patterns of pollinators were quantified. Because one species heavily dominated the pollination of this complex flower, only its movements were followed in detail. Whenever possible, an individual visitor was followed from first arrival to departure to quantify the number of flowers entered per visit and to determine the time spent on each flower. On five observation days, visitors were caught upon first arrival, dusted lightly with different colored fluorescent powders, and immediately released (see Frankie, 1973, for method). These bees almost always returned to forage within minutes after release. This method allowed determination of the number of different bees foraging at any one shrub and aided observations of movements to nearby shrubs.

I also quantified fruit and ovule set of the observed shrubs. I marked up to a maximum of 100 flowers per day per individual, each day with a distinctive color of tape. The percentage of fruit set per observation day and per individual, measured five days after visitation, was used as one measure of pollination. Observations were also made two and three weeks following flowering and mature fruits on each individual were counted four weeks after flowering, just prior to dispersal. The mean number of mature seeds per fruit per individual was based on a count of seeds in a maximum of 20 mature fruits for each day an individual was in flower.

The percentage ovule set per fruit per individual was used as the second measure of pollination. Ovule set of aborted fruits was quantified only for an individual's entire flowering period and not for specific observation days because aborted fruits were not identified by specific day. The ovule set of flowers yielding mature fruits was based on a count of swollen and unswollen ovules in a maximum of 20 fruits for each day an individual was in flower.

Measurements of fruit set and ovule set, determined as soon as detectable after visitation of flowers, are considered the most direct indicators of the level of pollination. 
TABLE 1. Identification of visitors to flowers of Hybanthus prunifolius, their time of occurrence ( $S=$ natural synchronous period, $A=$ induced asynchronous period $)$, and their commonness $(1=$ very common, $2=$ common, 3 = rare .

\begin{tabular}{|c|c|c|}
\hline Family & Species & $\begin{array}{l}\text { Occurrence } \\
\text { commonness }\end{array}$ \\
\hline \multicolumn{3}{|l|}{ I. Bees } \\
\hline$\overline{\text { Apidae }}$ & Melipona interrupta triplaridis Cockerell & $1 \mathrm{~S}, \mathrm{~A}$ \\
\hline Apidae & Melipona fasciata paraensis Ducke & $3 \mathrm{~S}$ \\
\hline Apidae & Eulaeama bombiformis & $3 \mathrm{~A}$ \\
\hline Anthophoridae & Paratetrapedia calcarata Cresson & I S,A \\
\hline Anthophoridae & Paratetrapedia xanthaspis Cockerell & $1 \mathrm{~S}, \mathrm{~A}$ \\
\hline Anthophoridae & Ceratina laeta Spinola & $1 \mathrm{~S}, \mathrm{~A}$ \\
\hline Anthophoridae & Exomalopsis zexmeniae Cockerell & $3 \mathrm{~S}$ \\
\hline Halictidae & Augochloropsis vesta Smith & $1 \mathrm{~S}, \mathrm{~A}$ \\
\hline Halictidae & Augochlora hallinani Michener & $2 \mathrm{~S}, \mathrm{~A}$ \\
\hline Halictidae & Augochlora sp. & $3 \mathrm{~A}$ \\
\hline \multicolumn{2}{|c|}{ Other Hymenoptera* } & $3 \mathrm{~S}, \mathrm{~A}$ \\
\hline \multicolumn{3}{|l|}{ II. Other* } \\
\hline \multicolumn{2}{|c|}{ Lepidoptera (Sphingidae) } & $3 \mathrm{~S}, \mathrm{~A}$ \\
\hline \multicolumn{2}{|c|}{ Lepidoptera (Hesperiidae)- 2 morphs } & $2 \mathrm{~S}, \mathrm{~A}$ \\
\hline \multicolumn{2}{|c|}{ Lepidoptera (unknown family) 4 or more morphs } & $3 \mathrm{~S}, \mathrm{~A}$ \\
\hline \multicolumn{2}{|c|}{ Hummingbirds -4 morphs, male and female } & $3 \mathrm{~S}, \mathrm{~A}$ \\
\hline
\end{tabular}

* Unknown number of species; individuals not collected or formally identified.

Any delay in measurement creates additional variables that influence final number of mature fruits and seeds. These variables may involve abortion due to seed predation, adjustment of size of maturing fruit and seed crop to resource availability, and possible brood reduction by the parent based on particular genetic qualities among potential offspring. Therefore, early fruit and ovule set are used to most accurately reflect only levels of visitation by pollinators.

To measure the distance of gene flow due to dispersal of seeds, I selected five shrubs well separated from other fruiting individuals. The shrubs' heights ranged from $1.5-2.5 \mathrm{~m}$. A one-meter wide strip of cheesecloth, beginning at the trunk and extending for $13 \mathrm{~m}$, was laid out in a direction chosen randomly. Seeds were counted and removed daily throughout the dispersal period.

Nonparametric tests were chosen in all statistical analyses because the sample sizes were small and the data were distributed in a non-normal fashion.

\section{RESULTS}

Species richness and behavior of visitors.-More than 22 species of visitors, including sphinx moths, butterflies, hummingbirds, and numerous bees foraged at flowers of Hybanthus (Table 1). As predicted, a high species richness of foragers was attracted to this highly ephemeral but abundant resource. This species richness contrasts sharply with that of species with steady-state individuals which tend to be visited by only one major group of pollinators (e.g., Euglossine bees or hummingbirds or sphinx moths). Furthermore, the number of visiting species within a pollinator group is also often low (e.g., 6-9 hummingbird species, Stiles, 1975; 3 species of large bees, Janzen, 1968; 3 species of Euglossine bees, Janzen, 1971). However, for reasons outlined below, despite the high species richness of visitors to the mass-flowering Hybanthus, only the eusocial bee, Melipona interrupta, was considered a major effective pollinator. It was both very abundant and foraged with a behavior that effected high 
TABLE 2. Morphology and behavior of major classes of visitors to flowers of Hybanthus prunifolius.

\begin{tabular}{|c|c|c|c|c|c|c|c|}
\hline Measurement & $\begin{array}{l}\text { Melipona } \\
\text { interrupta }\end{array}$ & $\begin{array}{l}\text { Paratet- } \\
\text { rapedia } \\
\text { calcarata }\end{array}$ & $\begin{array}{l}\text { Augo- } \\
\text { chloropsis } \\
\text { vesta }\end{array}$ & $\begin{array}{c}\text { Ceratina } \\
\text { laeta }\end{array}$ & $\begin{array}{l}\text { Hesperiidae } \\
\text { (blue morph) }\end{array}$ & $\begin{array}{l}\text { Humming- } \\
\text { birds } \\
\text { (4 morphs) }\end{array}$ & $\begin{array}{l}\text { Sphingidae } \\
\text { (1 morph) }\end{array}$ \\
\hline \multicolumn{8}{|l|}{ Dimensions: (mm) } \\
\hline Length & $12 *$ & 8 & 9 & 9 & inserts & inserts & inserts \\
\hline Width & 7 & 6 & 4 & 4 & proboscis & proboscis & proboscis \\
\hline Height & $6 * *$ & 4 & 4 & 3 & only & only & only \\
\hline Pollen placement & $\begin{array}{l}\text { dorsal } \\
\text { thorax }\end{array}$ & $\begin{array}{l}\text { pollen } \\
\text { basket }\end{array}$ & $\begin{array}{l}\text { hairs } \\
\text { over } \\
\text { all of } \\
\text { body }\end{array}$ & $\begin{array}{l}\text { hairy } \\
\text { hind } \\
\text { legs }\end{array}$ & none & $?$ & $?$ \\
\hline \multicolumn{8}{|l|}{ Observations: } \\
\hline Number of days & $12 * * *$ & 21 & 18 & 9 & 10 & 4 & 2 \\
\hline Number of visits & 584 & 217 & 95 & 31 & 34 & 19 & 4 \\
\hline \multicolumn{8}{|c|}{ Flowers visited per min } \\
\hline Sample size & 20 & 20 & 20 & 9 & 8 & 10 & 4 \\
\hline Mean & 5.7 & 1.8 & 1.9 & 2.2 & 5.6 & 7.3 & 21.4 \\
\hline SD & 2.3 & 0.6 & 0.5 & 0.6 & 3.4 & 4.1 & 2.7 \\
\hline \multicolumn{8}{|l|}{ Flowers per visit: } \\
\hline Sample size & 217 & 43 & 15 & 4 & 15 & 17 & 4 \\
\hline Mean & 9.3 & 4.6 & 4.2 & 4.5 & 5.2 & 8.8 & 94.0 \\
\hline $\mathrm{SD}$ & 10.6 & 3.5 & 3.6 & 1.1 & 3.2 & 6.4 & 48.2 \\
\hline
\end{tabular}

* Proboscis $=4 \mathrm{~mm}$; total length $=16 \mathrm{~mm}$. Distance from corolla entrance to nectar averages $9.8 \mathrm{~mm}$.

** This height is clearly sufficient to deflect the style which is required for pollination; distance from side of corolla to style averages 3 mm (with no movement of anterior petal).

*** 5 days $(100 \%)$ in nat. syn., 3 days (100\%) in induced syn., and 4 days (23\%) in induced asyn. pop.

amounts of pollination. This stingless bee is quite common in the tropics (Michener, 1974).

Non-hymenopteran visitors were not very common (Table 1). Since they inserted only the proboscis or bill to collect nectar, they were highly unlikely to cause the complex pollination mechanism to work.

Only five species (all Hymenoptera) were very common visitors (Table 1). All these bees except Melipona were slow moving (Table 2 ). The small bees typically had difficulty entering the flower, which requires sufficient weight to depress the large anterior petal. Because of this, they often entered the flower through the side of the corolla. They were small enough for the entire body to fit within the corolla chamber without necessarily deflecting the style (Table 2). These small bees were capable of grasping the style with their front legs causing release of pollen, but this movement could occur without other parts of the body necessarily being in contact with the stigmatic opening. The heavy loads of pollen on the hind legs or in the pollen baskets of some of the bees indicated that they were actively foraging for pollen (Table 2). This placement of the pollen load would not result in effective pollination.

By contrast, the size and behavior of Melipona correctly matched the specifications of the flower's morphology. This medium-sized bee moved rapidly and had no difficulty depressing the anterior petal (Table 2). It entered the flower in a prone position. Extension of its $4 \mathrm{~mm}$ proboscis to reach nectar caused the thorax to be in a position first to contact the stigmatic opening and then to be located near the pollen release area. The thorax was sufficiently thick that entering the corolla required deflection of the style, thus effectively operating the pollination mechanism.

Melipona stores pollen in an unusual location. Large quantities of pollen were 


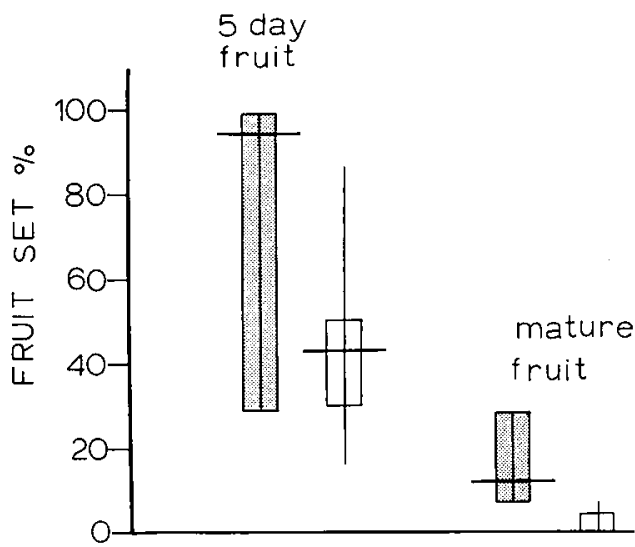

FIG. 1. Comparison of $\%$ of flowers remaining as fruits between observation days with visits by Melipona interrupta (shaded, $N=7$ days) and observation days with no visits by Melipona (unshaded, $N=13$ days). Data are given for fruit 5 days after flowering (=pollination level) and for mature fruits 4 weeks after flowering. Data represent only flowers open on the observation day. See Table 3 for total reproductive outcome over all days of flowering of these same observed individuals. Horizontal line represents median; vertical line, range; rectangle, 95\% CI for median. Statistical test for differences: 5 Day Fruit: Mann-Whitney $U=13.0, P<.01$; Mature Fruit: Mann-Whitney $U=11.0, P<.01$.

found on the dorsal thorax and almost none was transferred to the pollen baskets. The bee used its legs to actively pack down pollen on the thorax. This is the ideal position for consistently pollinating this flower.

Melipona began foraging at Hybanthus around $0700 \mathrm{~h}$ and ended at $1700-1800 \mathrm{~h}$, thus paralleling the period of nectar production. There was a steady rise in activity until $1200 \mathrm{~h}$ and a steady decline after $1200 \mathrm{~h}$.

During the brief burst of flowering of the shrub, Melipona was quite constant to that resource. I determined this constancy by examining, in Hoyer's medium, 500 pollen grains each from ten different bees. I found $99.7 \%$ of all grains to have the distinctive shape of Hybanthus. I also observed dyed individual bees maintaining constancy by returning to an individual shrub on successive days.

Fruit and ovule set.-Additional evidence of the effectiveness of Melipona as

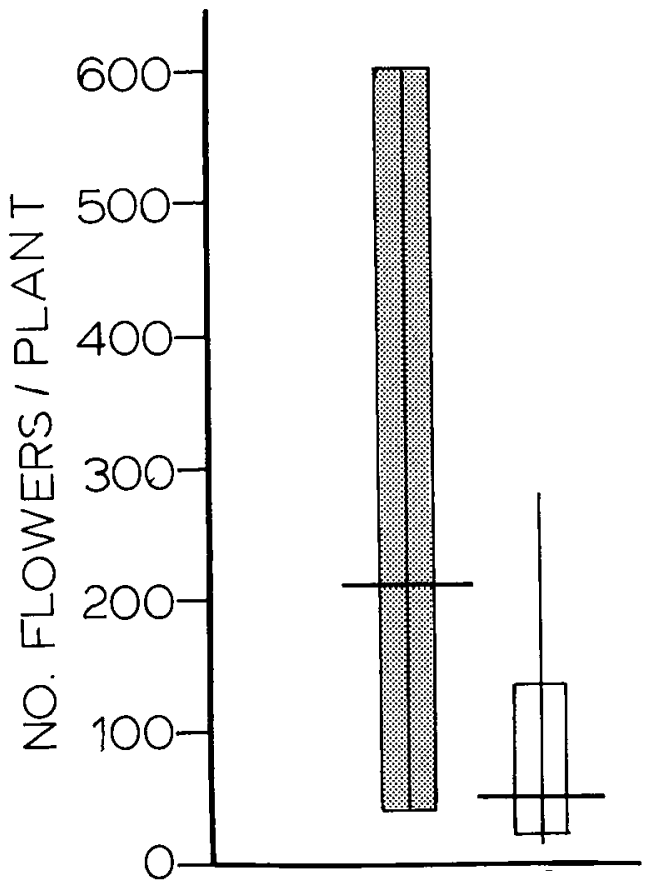

FIG. 2. Comparison of number of flowers between days of observation with visits by Melipona interrupta (shaded $=7$ days) and days with no visits by Melipona (unshaded, $N=13$ days) Statistical test for difference: Mann-Whitney $U=0, P<$ .001 .

a pollinator comes from fruit and ovule set percentages of asynchronously flowering individuals. Observation days in the experimental area were divided into two categories: days with and days without visits by Melipona. Days with visits by Melipona had a significantly higher percentage early fruit set per individual per observation day than days including no visits by that bee (Fig. 1). The percentage of mature fruits set was also significantly higher for those days.

The same trends apply to the overall fruit set of the experimental plants (Table 3). An individual visited by Melipona had $90 \%$ early fruit set, while an individual without visits by that bee had $43 \%$ early fruit set. The latter value indicates that pollination was effected by the smaller bees, but so high a value for early fruit set is misleading because only a negligible amount of these initially set fruits became 
TABLE 3. Comparison of ovule and fruit set between individuals visited by Melipona interrupta and individuals not visited by Melipona interrupta. Data represents totals for all days of flowering. All individuals observed were induced to flower out of synchrony with natural populations.

\begin{tabular}{|c|c|c|c|c|c|c|c|}
\hline Variable & Strata & $\begin{array}{l}\text { No. of } \\
\text { indiv. }\end{array}$ & Median & $95 \% \mathrm{CI}$ & Range & $\begin{array}{c}\text { Mann- } \\
\text { Whitney } \\
U=\end{array}$ & Significance \\
\hline \multicolumn{8}{|l|}{ Flower level } \\
\hline No. flowers & $\begin{array}{l}\text { with } M . i \text {. } \\
\text { without }\end{array}$ & $\begin{array}{r}7 \\
10\end{array}$ & $\begin{array}{r}655 \\
93\end{array}$ & $\begin{array}{r}(102-997) \\
(33-367)\end{array}$ & $\begin{array}{r}102-997 \\
30-514\end{array}$ & 9.0 & $P<.010$ \\
\hline$\%$ as fruits at 5 days & $\begin{array}{l}\text { with } M . i . \\
\text { without }\end{array}$ & $\begin{array}{r}7 \\
10\end{array}$ & $\begin{array}{l}89.5 \\
43.3\end{array}$ & $\begin{array}{l}(69.4-98.0) \\
(20.3-64.7)\end{array}$ & $\begin{array}{l}69.4-98.0 \\
16.3-75.7\end{array}$ & 1.0 & $P<.002$ \\
\hline$\%$ as mature fruits & $\begin{array}{l}\text { with } M . i \\
\text { without }\end{array}$ & $\begin{array}{r}7 \\
10\end{array}$ & $\begin{array}{r}16.7 \\
1.8\end{array}$ & $\begin{array}{l}(4.1-35.7) \\
(0.3-8.0)\end{array}$ & $\begin{array}{r}4.1-35.7 \\
0-13.3\end{array}$ & 6.0 & $P<.010$ \\
\hline \multicolumn{8}{|l|}{ Ovule level } \\
\hline $\begin{array}{l}\text { Mean no. ovules } \\
\text { per fruit }\end{array}$ & $\begin{array}{l}\text { with } M . i . \\
\text { without }\end{array}$ & $\begin{array}{r}7 \\
10\end{array}$ & $\begin{array}{l}27.7 \\
26.4\end{array}$ & $\begin{array}{l}(25.5-28.4) \\
(23.5-28.8)\end{array}$ & $\begin{array}{l}25.5-28.4 \\
23.3-30.2\end{array}$ & 29.0 & $P \stackrel{\text { n.s. }}{>}=.200$ \\
\hline $\begin{array}{l}\text { Mean \% ovules swollen } \\
\text { in aborted fruits }\end{array}$ & $\begin{array}{l}\text { with } M . i . \\
\text { without }\end{array}$ & $\begin{array}{r}7 \\
10\end{array}$ & $\begin{array}{l}53.6 \\
15.4\end{array}$ & $\begin{array}{r}(34.5-63.3) \\
(6.9-45.9)\end{array}$ & $\begin{array}{r}34.5-63.3 \\
6.9-49.2\end{array}$ & 5.0 & $P<.001$ \\
\hline $\begin{array}{l}\text { Mean } \% \text { ovules swollen } \\
\text { in mature fruits }\end{array}$ & $\begin{array}{l}\text { with } M . i \text {. } \\
\text { without }\end{array}$ & $\begin{array}{l}7 \\
5\end{array}$ & $\begin{array}{l}60.3 \\
44.0\end{array}$ & $\begin{array}{l}(22.8-81.1) \\
(17.3-77.4)\end{array}$ & $\begin{array}{l}22.8-81.1 \\
17.3-77.4\end{array}$ & 14.0 & $P<.050$ \\
\hline $\begin{array}{l}\text { Mean no. seeds } \\
\text { per fruit }\end{array}$ & $\begin{array}{l}\text { with } M . i . \\
\text { without }\end{array}$ & $\begin{array}{r}7 \\
10\end{array}$ & $\begin{array}{l}4.7 \\
2.9\end{array}$ & $\begin{array}{r}(2.3-5.5) \\
(0-7.2)\end{array}$ & $\begin{array}{l}2.3-5.5 \\
0-11.8\end{array}$ & 27.0 & $\begin{array}{c}\text { n.s. } \\
P>.200\end{array}$ \\
\hline
\end{tabular}

mature fruits and seeds. Of the early fruits set due to activity by the smaller bees, most had few swollen ovules and were later aborted (Table 3). As a result these individuals had almost no fruits develop to maturity. The percentage early ovule set per fruit per individual in both aborted and mature fruits was also significantly higher if the individual received visits by Melipona (Table 3).

To summarize the pollination effectiveness of Melipona relative to other visitors, I combined data from both fruit and ovule set. Seven times as many ovules were set (of total ovules available irrespective of specific fruit, day, or individual) among individuals with known visits by $\mathrm{Meli}$ pona (49\%) compared to individuals with no known visits by Melipona $(7 \%)$ in the experimental area. Although the days with visits by Melipona included visits by the smaller bees, the data suggest that a large majority of the fruit set on those days was effected by Melipona alone and that only a negligible amount of pollination leading to mature fruits and seeds was contributed by the smaller bees.
Density-dependent foraging. - Individuals visited by Melipona had a significantly greater number of flowers than individuals receiving no visits (Fig. 2). The major pollinator was attracted consistently only to high densities of floral resources. The level of attraction was strongly density-dependent at two levels: population and individual.

At the population level, all observed individuals received visits, regardless of size and regardless of whether they were in naturally flowering $(1975,1976)$ or induced (1976) synchronous populations $(N=11)$. In contrast, visitation to asynchronous individuals was erratic, occurring on only four of 17 days. These four days included two individuals with very high abundance of flowers and two individuals with more moderate amounts. Individuals with few flowers observed in the asynchronous population never received visits by Melipona.

At the individual level in the asynchronous population, percentage of fruit set increased significantly with an increase in the $1 \mathrm{n}$ number of flowers of an indi- 
TABLE 4. Movement and visitation patterns of Melipona interrupta.

\begin{tabular}{|c|c|c|c|c|}
\hline & Population observed & $\begin{array}{c}\text { Sample } \\
\text { size }\end{array}$ & Mean & Range \\
\hline $\begin{array}{l}\text { Different dyed bees per plant } \\
\text { per } 41 / 2 \mathrm{~h} \text { observation }\end{array}$ & 1976 Natural & 5 & 3.4 & $2-8$ \\
\hline $\begin{array}{l}\text { Bees simultaneously present } \\
\text { per observ. period }(15 \mathrm{~min})\end{array}$ & $\begin{array}{l}1976 \text { Natural } \\
1976 \text { Experimental }\end{array}$ & $\begin{array}{l}90 \\
21\end{array}$ & $\begin{array}{l}1.3 \\
2.0\end{array}$ & $\begin{array}{l}0-5 \\
0-5\end{array}$ \\
\hline $\begin{array}{l}\text { New entering visits per } \\
\text { observ. period }\end{array}$ & $\begin{array}{l}1975 \text { Natural } \\
1976 \text { Experimental }\end{array}$ & $\begin{array}{l}21 \\
72\end{array}$ & $\begin{array}{l}3.3 \\
2.4\end{array}$ & $\begin{array}{l}0-7 \\
0-7\end{array}$ \\
\hline $\begin{array}{c}\text { Flowers visited per } \\
\text { observ. period* }\end{array}$ & $\begin{array}{l}1975 \text { Natural } \\
1976 \text { Experimental }\end{array}$ & $\begin{array}{l}21 \\
72\end{array}$ & $\begin{array}{l}25.0 \\
21.0\end{array}$ & $\begin{array}{l}5-98 \\
0-64\end{array}$ \\
\hline $\begin{array}{l}\text { Foraging rate: } \\
\text { Flowers per minute }\end{array}$ & $\begin{array}{l}1975 \text { Natural } \\
1976 \text { Experimental }\end{array}$ & $\begin{array}{l}20 \\
20\end{array}$ & $\begin{array}{l}6.2 \\
5.7\end{array}$ & $\begin{array}{l}4-10 \\
2-9\end{array}$ \\
\hline $\begin{array}{l}\text { Visits per marked flower } \\
\text { per } 41 / 2 \mathrm{~h} \text { observation }\end{array}$ & 1976 Experimental & 24 & $2.1 * *$ & $1-4$ \\
\hline
\end{tabular}

* Visits by all $M$. intermpta.

** To calculate total number of visits per flower per day:

Method $1: 2 \times 4 \frac{1}{2} \mathbf{h}=$ total foraging period. Therefore each flower was visited $2 \times 2.1=4.2$ times per day.

Method 2: 25 flowers visited per 15 min interval $\times 36$ intervals in $9 \mathrm{~h}$ foraging period $=900$ flowers visited per day. Average number of flowers per individual shrub $=200$ (see Table 5). Therefore, each flower was visited 4.5 times per day.

vidual $(N=43)$. Simple linear regression analysis revealed a positive slope differing significantly from $0\left(Y=.23+.13 x, r^{2}=\right.$ $.19, P<.005)$. Temporally isolated individuals with larger numbers of flowers had more ability to attract Melipona consistently.

Movement patterns and estimation of cross-pollination.-An individual shrub was not visited by many bees at any one time. However, there was sufficient activity by Melipona alone to account for the very high percentage of early fruit set (90\%) (Table 4). I calculate that each flower was visited an average of four times by Melipona (see Table 4). Even with this high a level of visitation per flower, only $58 \%$ (range $=23-81$ ) of the ovules (of both aborted and mature fruits) were swollen per fruit per individual. Therefore, some factor other than pollinator activity may be limiting full ovule set.

Contrary to hypothesis two, individual bees did not stay for long periods at any one plant (Table 5). Regardless, the individual plant may still have been predominantly self-pollinated. A bee visited an average of roughly ten flowers per visit (5\% of the available flowers) (Table 5). There is a high probability that each visit was preceded by a visit to a conspecific (99.7\% of pollen examined in ten pollen loads was Hybanthus pollen). The resulting level of cross-pollination depends, in part, on the amount of pollen carry-over occurring past the first visited flower. If only the first visited flower received outcrossed pollen and the remaining nine received pollen from other flowers on the same plant, then $10 \%$ is an approximation of the maximum percentage of flowers being cross-pollinated. The opposite extreme is that all of the ten flowers received some foreign pollen. There are no data available to evaluate these two extreme levels of cross-pollination, but previous studies indicate that pollen carry-over may be minimal (Levin and Kerster, 1974). In one study, most pollen was deposited on the first stigma; little pollen was deposited beyond the third stigma visited (Levin and Berube, 1972). If comparable low levels of carry-over occur in Hybanthus, then the level of cross-self pollination may be close to $10 \%$, unless there was interaction between foreign and self pollen. The $10 \%$ estimation also rests on the assumption that each visit began at a previously unvisited flower. Since some visits began at previously pollinated flowers (a flower may have been visited four times), this behavior serves to further lower the level of cross-pollination.

A plant received about three new visits 
TABLE 5. Number of flovers entered by Melipona interrupta per visit to Hybanthus prunifolius. Data restricted to complete observations in which bee's approach to and exit from the plant were directly observed.

\begin{tabular}{|c|c|c|c|c|c|c|c|}
\hline \multirow[b]{2}{*}{ Population observed } & \multirow{2}{*}{$\begin{array}{l}\text { Number } \\
\text { of plants }\end{array}$} & \multirow{2}{*}{$\begin{array}{c}\text { Number of } \\
\text { complete } \\
\text { observations }\end{array}$} & \multicolumn{2}{|c|}{$\begin{array}{l}\text { Number flowers on } \\
\text { visited individuals }\end{array}$} & \multicolumn{2}{|c|}{$\begin{array}{l}\text { Number flower } \\
\text { entered per visit: }\end{array}$} & \multirow{2}{*}{$\begin{array}{c}\% \\
\text { Available } \\
\text { flowers } \\
\text { entered } \\
\text { per visit }\end{array}$} \\
\hline & & & Mean & Range & Mean & $\mathrm{SD}$ & \\
\hline 1975 Natural & 3 & 70 & 210 & $150-244$ & 7.4 & 7.8 & 3.7 \\
\hline 1976 Natural & 5 & 50 & 163 & $34-267$ & 13.8 & 13.8 & 8.5 \\
\hline 1976 Experimental & 5 & 97 & 276 & $187-599$ & 8.4 & 9.4 & 3.0 \\
\hline Total & 13 & 217 & 200 & $34-599$ & 9.8 & 10.6 & 4.9 \\
\hline
\end{tabular}

per 15 min interval or 120 visits per day by Melipona (with potential for cross-pollination) (Table 4). If the shrub were selfincompatible, and if it is assumed that one visit per flower results in a pollinated fruit and that visitation rates are comparable on all days, then it would have a maximum of $60 \%$ fruit set ( 120 of 200 flowers). If pollen is depleted early in the day or if some incoming bees have not previously visited Hybanthus, then some of the 120 visits may not effect pollination. Therefore, this $60 \%$ estimate is probably somewhat inflated. Being self-compatible in reality, the shrub actually has a much higher percentage of fruit set (83-91\% per individual in two seasons in natural synchronized populations).

An individual's reproductive contribution is also increased by outward flow of its pollen. The 120 incoming visits resulted in 120 exits of the bees carrying that plant's pollen. Some visits led to returns to the nest. But the remainder must have involved transfer of pollen to at least the first flower visited at a conspecific plant.

Inter-plant movement by the bee between conspecifics was common. The bee often flew to the nearest neighbor (average distance $=2.6 \mathrm{~m}$ ). Of those visits in which exits were observed $(N=70$ in 1975 ), the bee moved to a very local conspecific after $33 \%$ of those visits. After the remaining visits, the bee flew out of sight to unknown locations. Those locations were not necessarily far away. By staying constant to the observation plant, the observer was unable to locate undyed bees more than about $5 \mathrm{~m}$ away.
Gene flow by pollen and seeds.-The percentage of flowers experiencing crosspollination may be as low as $10 \%$. In addition, the cross-pollination that was observed was restricted to quite short distances within local populations. This pollen flow was also likely to have been between closely related individuals. Nearest neighbors are likely to be genetically related, in part because gene flow by seed is quite restricted in distance. The seeds are explosively dispersed an average of only $1.8 \mathrm{~m}$ (range $=0-11$ ) from the trunk of the parent shrub. Two-thirds of the seeds land within $3 \mathrm{~m}$ of the trunk (Fig. 3). Pollen flow to spatially close individuals, therefore, may not have constituted a great deal more movement of different genes than if the individual had experienced complete self-pollination.

\section{Discussion}

The two hypotheses tested concentrate on the relationship between a mass-flowering phenological pattern and pollinator attraction and movement. In the discussion to follow, evaluation of the two hypotheses is first summarized. Then consideration is given to additional variables that interact with the phenological pattern to influence levels of fruit and ovule set, cross-pollination, and gene flow. These variables are compatibility system, growth form, and the density of the population in time and space. Finally, emphasis is placed on the genetic consequences of the observed pollinator movement and seed dispersal and their combined impact on the effective population size and the pre- 


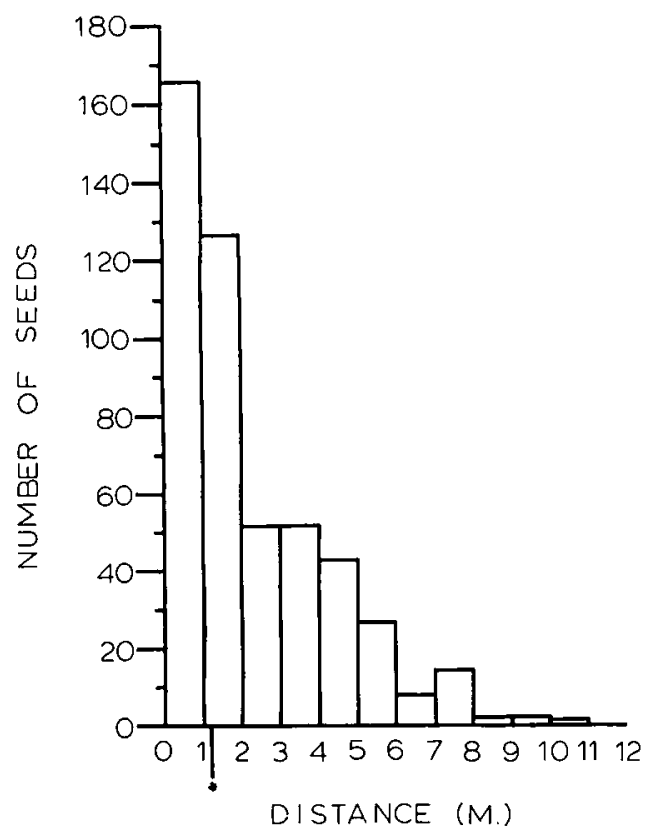

FIG. 3. Combined distribution of distances seeds were dispersed from 5 individuals of Hybanthus prunifolius. $N=494$ seeds. $0=$ trunk of shrub, * = edge of shrub canopy.

dicted amount of genetic variability in this mass-flowering shrub.

Contrary to the first hypothesis which predicted a high species richness of pollinators, Hybanthus prunifolius attracts a high species richness of visitors, but effective pollination is predominated by one social bee, Melipona interrupta. The study illustrates the necessity of carefully documenting the pollinating effectiveness of flower visitors rather than assuming all visitors to be equally effective pollinators. Beattie et al. (1973) predicted that the strategy of masses of self-compatible flowers exploiting a wide variety of insects would be found to be extremely common. This study of individuals with masses of self-compatible flowers does not support that prediction.

Contrary to the second hypothesis, the pollinator has a relatively short period of constancy to one mass-flowering individual and it often moves between conspecifics. Despite these frequent movements to conspecifics, it is possible that only a low percentage of an individual's flowers actually experience cross-pollination. Unless there is much pollen carry-over from flower to flower, even a few consecutive visits to flowers on the same individual (e.g., ten flowers visited consecutively on Hybanthus), probably greatly diminishes the amount of cross-pollination effected. The short period of constancy to one individual could, by itself, result in a low fruit set. However, the number of such short visits is so high that each flower may be visited as often as four times and the resulting fruit set is very high $(90 \%)$.

This study documents the impact of the individual's mass-flowering pattern on its ability to attract pollinators. An individual shrub may be using this pattern to compete with trees in attracting a pollinator common to both of them. The study shows that lone Melipona occasionally forage briefly at plants with low resources, but that a very large resource appears to be required to activate colony recruitment to a specific area. During two years of observation of understory shrubs in general, I had only rare encounters with Melipona at other than mass-flowering shrubs. I did observe Melipona actively foraging at large canopy trees at the island's edge where branches reach down into view. This suggests that the bee generally forages in the canopy and is attracted en masse to shrub flowers only under the unusual densities achieved by mass-flowering of the individual.

This mass-flowering shrub also has two population features which contribute to its appearance as an abundant floral resource. First, a population exists in high spatial density, and second, a population has a high degree of flowering synchrony. Given these additional components it follows that selection, then, would favor the individual shrub that is closest to its conspecifics in both time and space. Data testing this hypothesis are reported in detail elsewhere (Augspurger, 1978). Briefly, the data demonstrate that fruit and ovule set of an individual isolated in time and/or space is significantly lower than that of an individual in a population of high spatial 
density and flowering in synchrony with its conspecifics. Population properties of time and space, therefore, produce additive density effects in attracting the pollinator to the mass-flowering individual.

It may seem somewhat surprising to find a restrictive floral morphology in a mass-flowering individual, especially since the system seems to lack a reciprocal dependency on the pollinator. Actually, there are few oligolectic bees in the tropics (Michener, 1954; Linsley, 1958). Most tropical bees thus far studied have a low host specificity. Hybanthus thus relies heavily on one pollinator, but the pollinator depends on the ephemeral floral resources of Hybanthus for a very short period of the year. A Melipona colony is active year-round and thus is not dependent on any one or even a few floral resources.

Specialization by the plant is feasible, in large part, because of the plant's ability to attract a social bee. Kerr and Esch (1965) have shown that scouts of the genus Melipona actively recruit other colony foragers to newly found resources. Presumably this is the way in which Hybanthus is able to attract a large work force in response to its very abundant resource. A more generalized flower is predicted for a mass-flowering plant which does not attract a social bee with its large work force, but which instead depends on attracting large numbers of diverse pollinators such as solitary bees of differing morphologies and foraging behaviors.

Several hypotheses dealing with massflowering may have to be modified if they are to be applicable to shrubs in addition to trees. For example, Janzen (1971) suggested that mass-flowering may represent the production of an "excess" of flowers to attract large numbers of bees with irregular visitation behaviors. That hypothesis is less applicable to shrubs which have a much lower number of flowers than do trees. In Hybanthus there was no "excess" of the self-compatible flowers in relation to fruit production. The average individual had $90 \%$ fruit set and $60 \%$ seed set. However, the ratio of fruits/flowers in oth- er mass-flowering shrubs depends, additionally, on their compatibility systems.

Without self-compatibility, a massflowering individual is predicted to set a very low amount of fruit. Such an individual would then appear to have an "excess" of flowers. Such a low percentage fruit set has been verified for a large tropical tree, Andira inermis (Leguminosae), which is widely-spaced and which has self-incompatible flowers (Frankie et al., 1976). Its fruit set of $0.4-1.8 \%(N=5$ trees) was found to be due to limited intertree movement by solitary bees.

The present study suggests, however, that the hypothesis of incompatibility increasing outbreeding at the expense of decreased fruit set needs to be modified if shrub species of high spatial density are included. The data indicates that if $\mathrm{Hy}$ banthus were self-incompatible, it experiences enough pollinator movement to potentially realize a $60 \%$ fruit set. This level is substantially higher than for the widely spaced tree, Andira inermis.

In summary, the present evidence indicates that percentage of fruit set is not directly a consequence of a mass-flowering phenological pattern alone. It is also substantially influenced by compatibility system, growth form (e.g., shrub versus tree), and temporal and spatial densities of populations.

Finally, I consider the genetic consequences of the reproductive biology of Hybanthus on the effective population size and genetic variability of such populations. The restricted distance of seed dispersal has at least three major influences on pollinators and subsequent pollen flow. First, it contributes to the high spatial density of the population which is then effective in attracting more density-dependent pollinators. Second, and more importantly for pollen flow, the low seed dispersal and subsequent high density results in restricting much of the inter-plant movement by the pollinator to very short distances. Third, since the dispersal distance is restricted, much genetic mixing of individuals in a population does not take place either during seed dispersal or dur- 
ing pollination. Clusters of individuals in one generation are likely to be closely related to each other and to the same group of individuals they replaced. Consequently, any pollen flow that does occur over short distances is likely to be between closely related individuals. As a result, switching to self-compatibility may have little impact on the actual amount of genetic outbreeding. Alternatively, it can be argued that in the face of such potential genetic uniformity, self-incompatibility becomes especially important.

The accumulated evidence for low amounts and distances of gene flow by both pollen and seed in Hybanthus leads to three predictions: 1) effective population size is small; 2) genetic variability of individuals and populations may be low; and 3) local differentiation of populations may occur. The predictions accrue not merely from the original focus of this study, viz., the mass-flowering phenological pattern. They also depend on the additive effects of the shrub growth form, the self-compatibility system, the limited seed dispersal capability, the high population spatial density, and the high degree of population reproductive synchrony.

Allard et al. (1968) conclude, primarily from evidence of crops, that populations maintain a high degree of variability despite very low migration of genes between individuals and despite inbreeding systems. Evidence of genetic variability of tropical plant populations is scant (see Gan et al., 1977). Hybanthus prunifolius represents a potential study organism with interesting potential for studies of genetic variability.

\section{SUMMARY}

This phenological study tests two hypotheses: 1) Mass-flowering of an individual shrub serves to attract a large number and high species richness of "opportunistic" pollinators; and 2) Mass-flowering induces long periods of pollinator constancy to one individual which results in low inter-plant movement of pollen.

More than 22 species of insects and birds were observed to visit the flowers of the tropical shrub, Hybanthus prunifolius. However, high levels of effective pollination were restricted to the social bee, Melipona interrupta. This species showed highly density-dependent visitation responses at two levels: the individual massflowering plant and the highly synchronized population of plants.

An individual was constant to one shrub for a short time period and visited only $5 \%$ of available flowers per visit. But the large number of visits per day (120) resulted in a high fruit set and ovule set. The level of cross-pollination was estimated to be as low as $10 \%$. Pollen flow was commonly restricted to nearby neighbors (mean distance $=2.6 \mathrm{~m}$ ). Gene flow was further restricted by a low distance of dispersal of seeds (mean distance $=1.9$ $\mathrm{m})$. This mass-flowering shrub, therefore, does not experience a high level of gene flow.

The study also illustrates that levels of cross-pollination and fruit set are not determined solely by the phenological pattern of the individual plant. Pollination in this mass-flowering shrub is further influenced by its compatibility system, and the temporal and spatial densities of the population.

\section{ACKNOWLEDGMENTS}

I am grateful to G. Irvine, T. Beliz, and $P$. Amann for field assistance, to the many $\mathrm{BCI}$ residents for continual aid and support, and to the staff of the Smithsonian Tropical Research Institute for advice and encouragement. R. E. Silberglied conducted the UV analysis. C. D. Michener graciously identified the bees.

J. Affolter, G. Anderson, W. Anderson, G. Frankie, D. Janzen, A. Sakai, D. Rabinowitz, J. Vandermeer, and W. Wagner offered constructive comments on the manuscript. This research was conducted in partial fulfillment of the requirements for the $\mathrm{Ph} . \mathrm{D}$. at the University of Michigan. Funding was provided by a University of Michigan Rackham Predoctoral Fellowship and a Smithsonian Institution Predoctoral Fellowship. 


\section{Literature Cited}

Allakd, R. W., S. K. JAIN, AND P. L. WorkMAN. 1968. The genetics of inbreeding species. Advance. Genet. 14:55-131.

Asmton, D. H. 1975. Studies of flowering behavior in Eucalyptus regnans. Austral. J. Bot. 23:399412.

Augsburger, C. K. 1978. Reproductive consequences of flowering synchrony in Hybanthus prunifolius (Violaceae) and other shrub species of Panama. Ph.D. Thesis. Univ. of Michigan, Ann Arbor.

BAKER, H. G. 1959. Reproductive methods as factors in speciation in flowering plants. Cold Springs Harbor Symp. Quant. Biol. 24:177-199.

- 1973. Evolutionary relationships between flowering plants and animals in American and African tropical forest, p. 145-159. In E. J. Meggers, E. S. Ayensu, and W. D. Duckworth (eds.), Tropical Forest Ecosystems in Africa and South America: a Comparative Review. Smithsonian Institution Press, Washington, D.C.

BAWA, K. S. 1974. Breeding systems of tree species of a lowland tropical community. Evolution 28:85-92.

Beattie, A. J. 1971. Pollination mechanisms in Viola. New Phytol. 70:343-360.

Beattie, A. J., D. E. Breedlove, ANd P. R. EhrLICH. 1973. The ecology of the pollinators and predators of Frasera speciosa. Ecology 54:81-91.

BorRero, J. I. 1972. Explotación de las flores de guayacán (Tabebuia chrysantha) por varias especies de aves e insectos. Biotropica 4:28-31.

CARPenter, F. L. 1976. Plant-pollinator interactions in Hawaii: pollination energetics of Metrosideros collina (Myrtaceae). Ecology 57:11251144.

Corner, E. J. H. 1940. Wayside Trees of Malaya. Govt. Print. Office, Singapore.

Federov, A. A. 1966. The structure of the tropical rain forest and speciation in the humid tropics. J. Ecol. 59:1-11.

FRANKIE, G. W. 1973. Field technique for marking bees with fluorescent powders. Ann. Entomol. Soc. Amer. 66:690-691.

ㄴ. 1974. Tropical phenology: applications for studies in community ecology, p. 287-296. In H. Lieth (ed.), Phenology and Seasonal Modeling. Springer-Verlag, N.Y.

Frankie, G. W., P. A. Opler, and K. S. Bawa. 1976. Foraging behavior of solitary bees: implications for outcrossing of a neo-tropical tree species. J. Ecol. 64:1049-1057.
Gan, Y-Y., F. W. Robertson, P. S. Ashton, E. Soepadmo, AND D. W. LEe. 1977. Genetic variation in wild populations of rain-forest trees. Nature 269:323-325.

Gentry, A. H. 1974. Flowering phenology and diversity in tropical Bignoniaceae. Biotropica 6:54-68.

GILBERT, L. E. 1975. Ecological consequences of a coevolved mutualism between butterflies and plants, p. 210-240. In L. E. Gilbert and P. H. Raven (eds.), Coevolution of Animals and Plants. Univ. of Texas Press, Austin.

Heinrich, B., AND P. H. Raven. 1972. Energetics and pollination ecology. Science 176:597-602.

JANZEN, D. H. 1967. Synchronization of sexual reproduction of trees within the dry season in Central America. Evolution 21:620-637.

- 1968. Reproductive behavior in the Passifloraceae and some of its pollinators in Central America. Behavior 32:33-48.

- 1971. Euglossine bees as long-distance pollinators of tropical plants. Science 171:203-205.

KENNEDY, H. A. 1974. Pollination and systematics of the "close-flowered" species of Calathea (Marantaceae). Ph.D. Thesis. Univ. of Calif., Davis.

KERR, W. E., AND H. Esch. 1965. Communicacãs entre as abelhas socieis brasileiras e sua contribuicão para o entendimento da sua evolucão. Ciencia e Cult. 17:529-538.

Levin, D. A., AND D. E. Berube. 1972. Phlox and Colias: the efficiency of a pollinator system. Evolution 26:242-250.

Levin, D. A., AND H. W. Kerster. 1974. Gene flow in seed plants. Evol. Biol. 7:139-220.

LiNhART, Y. B. 1973. Ecological and behavioral determinants of pollen dispersal in hummingbirdpollinated Heliconia. Amer. Natur. 107:511523.

Linhart, Y. B., AND J. A. Mendenhall. 1977. Pollen dispersal by hawkmoths in a Lindenia rivalis Benth. population in Belize. Biotropica 9:143.

Michener, C. D. 1954. Bees of Panama. Amer. Mus. Nat. Hist. Bull. 104:1-176.

_. 1978. The Social Behavior of the Bees. Harvard Univ. Press, Cambridge.

Stiles, F. G. 1975. Ecology, flowering phenology, and hummingbird pollination of some Costa Rican Heliconia species. Ecology 56:285-301.

WoLF, L. L. 1970. The impact of seasonal flowering on the biology of some tropical hummingbirds. Condor 72:1-14.

Corresponding Editor: R. Ornduff 